\title{
PENENTU INTENSI PEMBELIAN TIKET PESAWAT ONLINE
}

\author{
Zahrida Wiryawan $^{1}$, Nur Hidayah ${ }^{2}$, Thea Herawati $\mathbf{R}^{3}$, dan Ida Puspitowati ${ }^{4}$ \\ ${ }^{1}$ Jurusan manajemen, Universitas Tarumanagara Jakarta \\ Email:zahridaw@fe.untar.ac.id \\ ${ }^{2}$ Jurusan manajemen, Universitas Tarumanagara Jakarta \\ Email: nuridaumarudin@gmail.com \\ ${ }^{3}$ Jurusan manajemen, Universitas Tarumanagara Jakarta \\ Email:theah@fe.untar.ac.id ac.id \\ ${ }^{4}$ Jurusan manajemen, Universitas Tarumanagara Jakarta \\ Email: idap@fe.untar.ac.id
}

\begin{abstract}
ABSTRAK
Penelitian ini bertujuan untuk menjelaskan faktor penentu intensi pembelian tiket pesawat secara online, yang meliputi kualitas jasa internet, persepsi penggunaan, pemahaman risiko, persepsi harga, kepercayaan online, dan pengetahuan internet terhadap intensi pembelian tiket online. Penelitian dilakukan terhadap 300 responden yang pernah berpergian dengan menggunakan aplikasi pembelian tiket secara online. Teknik pengumpulan data dengan menyebarkan kuesioner pada responden yang terpilih sebagai anggota sampling. Teknik analisis dengan single dan multiple regression dengan menggunakan program Smartpls. Hasil dari penelitian menunjukkan kualitas jasa internet dan pengetahuan internet tidak berpengaruh, artinya tidak dapat digunakan sebagai prediktor intense pembelian tiket online. Sedangkan pemahaman risiko, persepsi harga, kepercayaan online, berpengaruh terhadap intense pembelian tiket online. Hasil penelitian tersebut diharapkan dapat memberikan kontribusi bagi pengelola tiket online untuk memperhatikan faktor yang menjadi intensi konsumen berbelanja tiket secara online. Perlu adanya perbaikan atas kualitas jasa tiket online dan pengetahuan internet terhadap tiket online, agar dapat menjadi dasar bagi intensi keputusan konsumen dalam melakukan pembelian. Selain itu untuk persepsi pengguna, pemahaman resiko, harga dan kepercayaan tiket secra online terus harus dapat ditingkatkan karena ke empat hal ini memberikan pengaruh pada intensi pembelian konsumen
\end{abstract}

Kata kunci: factor penentu, intense pembelian, tiket online

\section{PENDAHULUAN}

\section{Latar Belakang}

Dunia saat ini menghadapi era informasi, yang ditandai dengan banyaknya pengguna internet, dan semakin banyak layanan yang diberikan melalui internet. Salah satunya pemasaran melalui internet adalah pembelian tiket. Cara ini telah memberikan kemudahan dan keamanan bagi para konsumen.

Banyaknya tiket elektronik sudah yang dipergunakan Indonesia. Mengakibatkan semakin banyak maskapai yang menawarkan penerbangan dengan harga murah atau melakukan promosi untuk rute domestik maupun internasional melalui situs web mereka. Beberapa peneliti sebelumnya seperti Nikhashemi, dkk. (2012), menemukan bahwa keinginan konsumen untuk membeli tiket secara online dipengaruhi oleh kualitas jasa, persepsi penggunaan, pemahaman risiko, persepsi harga, pengetahuan internet, dan kepercayaan online.. Penentuan harga di situs web merupakan hal yang sensitif, kompleks, dan kritis. Hal tersebut dapat memberi dampak positif maupun negatif terhadap keputusan pembelian konsumen (Tzy-Wen Tang, et al., 2005). Selain itu, konsumen juga harus memahami risiko yang dapat terjadi jika melakukan pembelian secara online. Risiko yang dapat terjadi seperti penipuan kartu kredit. Konsumen harus mempunyai pemahaman akan internet dan berbelanja di situs web yang terpercaya. Dalam konteks bisnis online, kepercayaan konsumen merujuk pada keyakinan dan ekspektasi mereka terhadap karakter penjual jasa online tersebut (Tzy-Wen Tang, et al., 2005). Kualitas jasa internet terdiri dari personalisasi, keamanan situs web, dan desain situs web. Kualitas jasa dapat ditentukan melalui perbedaan antara layanan yang diharapkan dengan layanan yang diterima atau dirasakan (Zeithaml, et al., 2002). Situs web yang dipilih konsumen adalah situs web yang berkualitas, 
maksudnya dapat memenuhi kebutuhan konsumen secara personal, dapat menjamin keamanan data konsumen, serta memiliki desain situs yang menarik. Faktor-faktor tersebut dapat menjadi hal utama yang dipikirkan oleh konsumen untuk menjadi faktor pendorong dalam mengkonsumsi sebuah jasa internet dan meningkatkan intensi pembelian.

Meningkatnya pengguna internet tersebut, menarik pelaku bisnis untuk melakukan penjualan produknya melalui internet, termasuk melakukan pembelian tiket secara online telah menjadi perhatian bagi maskapai penerbangan dan telah menimbulkan tantangan baru bagi para pemasar. Oleh karena itu perlu dilakukan penelitian tentang pengaruh persepsi kemudahan, persepsi penggunaan, pemahaman risiko, persepsi harga, kepercayaan online, dan pengetahuan internet terhadap intensi pembelian tiket pesawat onlinepada konsumen yang terdapat di Jakarta. Dengan mengkaji beberapa persoalan yang perlu diselesaikan yaitu:1). Apakah terdapat pengaruh kualitas jasa internet terhadap intensi pembelian konsumen? 2). Apakah terdapat pengaruh persepsi penggunaan terhadap intensi pembelian konsumen? 3). Apakah terdapat pengaruh pemahaman risiko terhadap intensi pembelian konsumen? 4). Apakah terdapat pengaruh persepsi harga terhadap intensi pembelian konsumen? 5). Apakah terdapat pengaruh kepercayaan online terhadap intensi pembelian konsumen? 6). Apakah terdapat pengaruh pengetahuan internet terhadap intensi pembelian konsumen? 7). Sedangkan yang menjadi tujuan pernelitian adalah: untuk mengetahui kualitas jasa internet, persepsi penggunaan, pemahaman risiko, persepsi harga, kepercayaan online, dan pengetahuan internet dapat atau tidaknya digunakan sebagai prediktor intensi pembelian tiket pesawat onlinepada konsumen di wilayah jakarta.

\section{Kualitas jasa internet}

Collier dan Bienstock (2006) mendefinisikan kualitas jasa internet, sebagai persepsi konsumen terhadap hasil dari layanan dengan pemulihan persepsi jika terjadi masalah. Fassnacht dan Koese (2006) menambahkankualitas jasa internet adalah, sejauh mana layanan elektronik mampu memenuhi kebutuhan pelanggan yang relevan secara efektif dan efisien.Menurut (Zeithaml, 2002), kualitas didefinisikan sebagai persepsi pelanggan terhadap keseluruhan kualitas dan keunggulan sebuah produk barang atau jasa berkenaan dengan tujuan yang dimaksudkan, relatif terhadap alternatif lain.

\section{Persepsi pengguna}

McGee, Rich, dan Dumas (2004), persepsi pengguna adalah persepsi anda tentang bagaimana konsisten, efisien, produktif, terorganisir, mudah digunakan, intuitif, dan sederhana untuk menyelesaikan tugas dalam suatu sistem.Pinelle et al. (2003),persepsi penggunaan sejauh mana orang percaya bahwa menggunakan kolaborasi teknologi tertentu dapat meningkatkan efisiensi dan efektivitas sebuah tugas dengan kepuasan.

\section{Pemahaman risiko}

Naiyi (2004) berpendapat bahwa pemahamanrisiko yang dirasakan adalah sebuah konsep mendasar dalam perilaku konsumen yang mengindikasikan pengalaman ketidakpastian sebelum membeli konsumen dalam hal jenis dan tingkat dari kerugian yang diperkirakan yang dihasilkan dari pembelian dan penggunaan sebuah produk. Dowling \& Staelin (1994 dalam Heijden, Verhagen, dan Creemers, 2003), berpendapat risiko yang dirasakan dapat dianggap sebagai fungsi subjektif konsumen dari besarnya konsekuensi yang merugikan dan probabilitas bahwa konsekuensi ini dapat terjadi jika produk diperoleh.Dapat dikatakan pemahaman risiko adalah suatu pemahaman mengenai ketidakpastian akan kerugian yang dapat dialami konsumen saat mengkonsumsi sebuah produk atau jasa secara virtual. 


\section{Persepsi harga}

Peter dan C.Olson (2000) berpendapat persepsi harga berkaitan dengan bagaimana informasi yang diperoleh konsumen dan anggapan atau pandangan konsumen tentang harga yang ditetapkan perusahaan.Melalui pendapat ini dapat dikatakan persepsi harga adalah pertimbangan mental yang dirasakan dan dipikirkan oleh konsumen,setelah mendapatkan informasi tentang harga. Dengan demikian konsumen dapat mengambil keputusan yang tepat sebelum membeli sebuah produk atau jasa.

\section{Kepercayaan online}

Bart et al., (2005), mengemukakan kepercayaan online mencakup persepsi konsumepn tentang seberapa besar situs web dapat memenuhi harapan, seberapa terpercaya informasi situs web itu, dan seberapa besar keyakinan perintah situs web.Kolsaker dan Payne, (2002) juga berpendapat bahwa sebagai dimensi dari hubungan bisnis yang menentukan tingkat dimana masing-masing pihak merasa bahwa mereka dapat bergantung pada integritas janji yang ditawarkan oleh pihak lain.

\section{Pengetahuan internet}

Pavlow(2006) berpendapat bahwa pengetahuan internet terdiri dari dua aspek yang penting dalam sebagian besar penggunaan internet; apa yang orang ketahui tentang internet dan apa yang dapat dilakukan orang dengan menggunakan internet.Lebih lanjut lagi, Lin dan Wang (2006) menambahkan, pengetahuan internet adalah apa yang orang ketahui tentang suatu teknologi tertentu (internet) serta berbagai macam hal yang orang bisa lakukan dengan menggunakan teknologi tersebut.Jadi, pengetahuan internet adalah suatu hal yang berhubungan dengan teknologi yang diketahui orang dan dapat digunakan oleh orang tersebut untuk menunjang pekerjaannya.

\section{Intensi pembelian}

Ajzen (2005) berpendapat bahwa intensi pembelian berarti sebuah kecenderungan yang subjektif yang dimiliki oleh konsumen terhadap sebuah produk tertentu, dan telah dibuktikan menjadi sebuah kunci untuk memprediksi perilaku konsumen. Blackwell (2006), menambahkan intensi penilaian subjektif tentang bagaimana kita bersikap di masa depan. Jadi, intensi pembelian adalah suatu proses evaluasi konsumen dengan penilaian subjektif terhadap suatu produk yang dapat memberikan stimulus sebelum terjadinya pembelian, sehingga pemasar dapat menjadikan intensi pembelian sebagai prediktor perilaku konsumen di masa depan.

\section{Pengaruh kualitas jasa internet terhadap intensi pembelian}

Cai dan Jun (2003) menyatakan bahwa, pertama kualitas jasa internet sangat mempengaruhi kepuasan konsumen dan intensi pembelian online. Kedua, kualitas jasa internet sangat penting dalam menarik pelanggan potensial. Calin (2003) menambahkan, daripada mencoba untuk meningkatkan kualitas jasa internet secara asal, perusahaan sebaiknya merancang dan mengimplementasikan sebuah program yang realistis untuk mencapai tingkat optimum dari kualitas jasa internet dan hal itu merupakan komponen penting dari strategi sentris konsumen.Zeithaml (2002) menambahkan, penjualan online gagal karena kualitas jasa yang buruk yang berdampak pada konsumen mereka.

\section{Pengaruh persepsi penggunaan terhadap intensi pembelian}

Persepsi penggunaan adalah tentang kegunaan yang mudah dan hal itu mempunyai dampak yang positif dalam perilaku pembelian konsumen untuk mengambil suatu keputusan.. Koufaris (2002 dalam Chi et al., 2005) menambahkan persepsi penggunaan untuk pembelian online sebagai 
probabilitas subjektif calon konsumen bahwa menggunakan internet dapat memfasilitasi pembelian yang dilakukannya dengan efisien. Persepsi penggunaan yang tinggi dapat timbul jika konsumen merasakan penggunaan yang mudah dan nyaman dalam mencari informasi dan melakukan transaksi di situs web tertentu. Dari studi yang dilakukan Barnes dan Vidgen (2006), dapat diketahui bahwa persepsi konsumen terhadap penggunaan situs web seperti mudah dipelajari dan dioperasikan, mudah dinavigasikan, mudah digunakan dan interaksi dengan situs web tersebut jelas dan dapat dimengerti.

\section{Pengaruh pemahaman risiko terhadap intensi pembelian}

Konsumen merasakan adanya risiko dalam setiap situasi pembelian. Tetapi, tingkat risikonya berbeda tergantung pada cara berbelanja. Dehbashi \& Nahavandi (2007) pemahaman risiko mengacu pada ketidakpastian akan adanya kemungkinan negatif dalam pembelian tiket secara online, terutama pada penyedia jasa penerbangan murah. Sementara itu Naiyi. (2004) disebutkan bahwa pemahaman risiko mempengaruhi intensi pembelian secara langsung.

\section{Pengaruh persepsi harga terhadap intensi pembelian}

Harga merupakan salah satu komponen yang paling penting yang dapat mempengaruhi keputusan konsumen dalam transaksi online. Menurut Lichtenstein et al. (1993) persepi harga adalah suatu proses dimana konsumen menerjemahkan harga menjadi kesadaran mental yang berarti. Persepsi harga adalah suatu isu yang rumit dan kritis yang dapat menstimulasi konsumen secara negatif maupun positif. Oleh sebab itu, mereka tidak yakin bahwa apa yang disajikan di situs web akan konsisten dengan yang disampaikan atau diterima. Demikian juga persepsi harga mempunyai peran penting dalam menentukan kepuasan dan intensi pembelian kembali (Van,2003).

\section{Pengaruh Kepercayaan Onlineterhadap Intensi Pembelian}

Menurut Kolsaker dan Payne (2002) kepercayaan didefinisikan sebagai sebuah dimensi dari hubungan bisnis yang menentukan tingkat dimana masing-masing pihak, yang merupakan syarat utama konsumen ingin melakukan pembelian online. Seorang konsumen harus memperhatikan apakah ia percaya pada sistem yang memfasilitasi transaksi (yaitu internet), percaya pada perusahaan yang sedang diajak berinteraksi online, dan percaya pada pihak ketiga untuk menjaga pertukaran sebelum keputusan membeli online dibuat.

\section{Pengaruh Pengetahuan Internet terhadap Intensi Pembelian}

Menurut Lin dan Wang (2006), pengetahuan memiliki hubungan yang positif dengan kepercayaan dan dalam kasus belanja serta transaksi online, hal itu mengarah pada motivasi bagi mereka yang berniat untuk melakukan belanja online. Ini berarti pengetahuan konsumen dapat menentukan tingkat kepercayaan mereka kepada penjual online dan intensi mereka untuk melakukan pembelian online. Dengan memiliki pengetahuan tentang internet, para konsumen dapat melindungi diri mereka dari segala kemungkinan buruk yang dapat muncul selama melakukan kegiatan belanja online.

\section{Model dan Hipotesis Penelitian}

Dalam penelitian ini, faktor-faktor yang memiliki kemungkinan berdampak pada pembelian tiket online adalah persepsi penggunaan, pemahaman risiko, kepercayaan online, persepsi harga dan pengetahuan internet serta kualitas jasa internet. Hal yang mendorong konsumen untuk terlibat dalam kegiatan online. Untuk itu model penelitian yang dapat ditawarkan adalah 


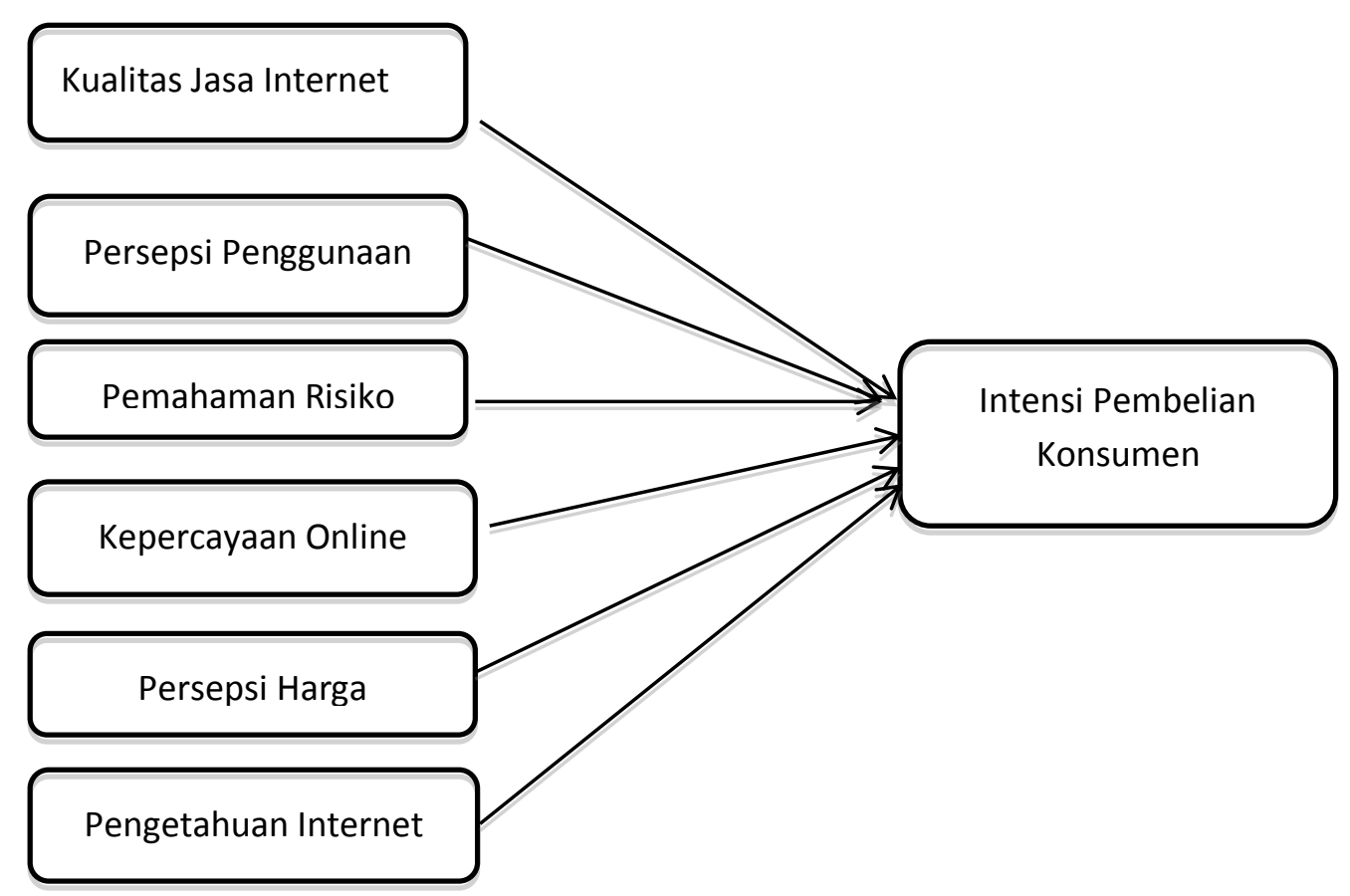

Gambar 1. Model Penelitian

\section{Hipotesis}

Berdasarkan model penelitian, maka hipotesis penelitian adalah:

H1: Terdapat pengaruh yang signifikan kualitas jasa internet terhadap intensi pembelian tiket pesawat online.

$\mathrm{H} 2$ : Terdapat pengaruh yang signifikan persepsi penggunaan terhadap intensi pembelian tiket pesawat online.

H3: Terdapat pengaruh yang signifikan pemahaman risiko terhadap intensi pembelian tiket pesawat online.

H4: Terdapat pengaruh yang signifikan kepercayaan online terhadap intensi pembelian tiket pesawat online.

H5: Terdapat pengaruh yang signifikan persepsi harga terhadap intensi pembelian tiket pesawat online.

H6: Terdapat pengaruh yang signifikan pengetahuan internet terhadap intensi pembelian tiket pesawat online.

\section{METODE PENELITIAN}

Penelitian ini dilakukan pada konsumen yang memesan tiket secara online selama 2 tahun terakhir saat kegiatan penelitian ini dilakukan yang berada di wilayah Jakarta. Sedangkan jangka waktu penelitian dimulai dari bulan Januari sampai dengan Juli 2017. Konsumen secara sampel dengan purposive sampling, karena responden yang dipilih sebagai sampel memilki kriteria yang telah ditentukan sesuai dengan tujuan penelitian.Dipilih sampel sebanyak 300 responden, yang tersebar di wilayah Jakarta. Hal ini berdasarkan pada pendapat Rust dan Golombok (1989) dalam Aritonang (2007), menyatakan bahwa dalam konteks pengujian reliabilitas, diambil minimal 200 responden.

\section{Pengukuran}

Untuk mengukur faktor penentu yang mempengaruhi intensi pembelian tiket pesawat online yang meliputi : Kualitas jasa internet, persepsi pengguna, pemahaman risiko, persepsi harga, 
kepercayaan online, dan pengetahuan internet terhadap intensi pembelian tiket pesawat onlinepada konsumen yang terdapat di Jakarta pada table berikut:

Tabel 1. Kualitas Jasa Internet

\begin{tabular}{|c|c|}
\hline Variabel & Indikator \\
\hline $\begin{array}{l}\text { Kualitas Jasa } \\
\text { Internet }\end{array}$ & $\begin{array}{l}\text { - Pentingnya keamanan situs web. } \\
\text { - Situs web tersebut memperhatikan kebutuhan pribadi saya. } \\
\text { - Merasakan bahwa situs web maskapai penerbangan sangat aman. } \\
\text { - Mempunyai tampilan visual yang rapi (terorganisasi dengan baik). }\end{array}$ \\
\hline $\begin{array}{l}\text { Persepsi } \\
\text { Pengguna }\end{array}$ & $\begin{array}{l}\text { - Pembelian online yang nyaman. } \\
\text { - Perasaan yang menyenangkan ketika membeli online. } \\
\text { - Kemudahan penggunaan situs tiket pesawat online. } \\
\text { - Menghemat waktu dengan berbelanja secara online. } \\
\text { - Tiket online memberikan banyak pilihan. }\end{array}$ \\
\hline $\begin{array}{l}\text { Pemahaman } \\
\text { Risiko }\end{array}$ & $\begin{array}{l}\text { - Kesediaan untuk melakukan pembayaran online. } \\
\text { - Rasa takut untuk membeli secara online. } \\
\text { - Merasa bebas tentang informasi pribadi. } \\
\text { - Selalu peduli terhadap pembayaran online. } \\
\text { - Memiliki pengaruh yang kuat pada kegiatan online }\end{array}$ \\
\hline $\begin{array}{l}\text { Persepsi } \\
\text { Harga }\end{array}$ & $\begin{array}{l}\text { - } \text { Murah } \\
\text { - } \text { terjangkau. } \\
\text { - Harga tidak memberi dampak. } \\
\text { - Harga mempunyai peran penting. }\end{array}$ \\
\hline $\begin{array}{l}\text { Kepercayaan } \\
\text { Online }\end{array}$ & $\begin{array}{l}\text { - Percaya kepada pembayaran online. } \\
\text { - Dapat merasakan situs web yang terpercaya. } \\
\text { - Informasi yang cukup tentang situs web memberikan perasaan aman. } \\
\text { - Sistem yang berkualitas memberikan rasa percaya. } \\
\text { Dampak terhadap keamanan situs web. }\end{array}$ \\
\hline $\begin{array}{l}\text { Pengetahuan } \\
\text { Internet }\end{array}$ & $\begin{array}{l}\text { - Memiliki pengetahuan akan internet sangat membantu. } \\
\text { - Mengetahui internet akan memberi kontribusi dalam mengurangi } \\
\text { risiko. } \\
\text { - Saya akan menjadi lebih yakin dalam melakukan transaksi online. } \\
\text { - Orang yang terampil akan termotivasi untuk membeli tiket secara } \\
\text { online. } \\
\text { - Menetahui cara menggunakan online }\end{array}$ \\
\hline
\end{tabular}

Sumber: Nikhashemi et al. (2012) 


\section{Intensi pembelian}

Intensi pembelian adalah suatu proses evaluasi konsumen dengan penilaian subjektif terhadap suatu produk yang dapat memberikan stimulus sebelum terjadinya pembelian, sehingga pemasar dapat menjadikan intensi pembelian sebagai prediktor perilaku konsumen di masa depan.Menurut Heijden,Verhagen\&Creemers(2003)intensi pembelian memiliki beberapa indikator sebagai berikut:

Tabel 2. IndikatorIntensi Pembelian

\begin{tabular}{|c|ll|}
\hline Variabel & \multicolumn{1}{c|}{ Indikator } \\
\hline Intensi Pembelian & • Sesuai dengan manfaat ekonomi. \\
& - Berkeinginan kuat berbelanja \\
& - Bersedia membayar berapapun \\
& - Memiliki sikap positif \\
\hline
\end{tabular}

Sumber: Heijden., Verhagen.,\&Creemers(2003)

\section{Teknik pengumpulan data dan analisis}

Pengguna tiket online sebagai responden penelitian diminta memberikan jawaban atas sejumlah pertanyaan-pertanyaan yang diajukan oleh peneliti atas tanggapannya tentang faktor penentu tiket online dan intensi pembelian tiket online. Format angket tersebut menggunakan skala Likert yang dimodifikasi bergerak dari 1 sampai 7 yaitu Sangat tidak setuju sampai sangat setuju sekali.

Instrumen yang digunakan untuk memperoleh data dalam penelitian ini harus diuji validitas dan reliabilitasnya. Untuk menguji Validitas suatu instrumen secara empiris menurut Aritonang (2007), salah satu cara yang dapat ditempuh adalah dengan menggunakan pendekatan validitas internal melalui analisis korelasi antara skor tiap butir dan skor total yang diperoleh semua subjek. Analisis uji validitas ini dapat menggunakan program SPSS. Reliabilitas diuji dengan analisis alpha Cronbach.

Jika butir-butir pertanyaan / pernyataan mendapatkan hasil corrected itemto total correlation minimal 0,2, menurut pendapat Aritonang (2007) maka butir-butir pertanyaan dinyatakan valid. Menurut pendapat Mudrajat (2003) jika butir-butir pertanyaan dikatakan reliabel jika menunjukkan alpa lebih besar atau sama dengan 0,7 .

Dalam penelitian ini analisis data menggunakan pendekatan Partial Least Square (PLS). PLS adalah model persamaan Structural Equation Modeling (SEM) yang berbasis komponen atau varian. Partial Least Square (PLS)

\section{HASIL DAN PEMBAHASAN}

\section{Hasil Penelitian}

Deskripsi subyek penelitian

Dalam deskripsi subyek penelitian ini akan diuraikan karakteristik respoden ditinjau dari jenis kelamin, usia, pendidikan dan Fluktuasi pembelian tiket online, dari 300 responden yang diambil sebagai sampel penelitian. Di mana responden yang memberikan penilaian dari kuesioner yang lebih banyak adalah wanita dengan selisih 3,4\%. Dengan usia berada pada usia 
30 sampai 40 tahun, tingkat pendidikan terbanyak berada pada tingkat pendidikan dan memberikan informasi frekuensi pembelian tiket online berada diposisi 5 sampai 7 kali .

\section{Deskripsi obyek penelitian}

Deskripsi obyek penelitian berisi tanggapan responden atas kelompok pernyataan pada yang terdiri atas: kualitas jasa internet, persepsi penggunaan, pemahaman risiko, persepsi harga, kepercayaan online, dan pengetahuan internet serta intensi pembelian tiket online .

Statistik deskriptif dari jawaban responden menunjukkan bahwa secra rata rta jawaban responden di posisi 4,52 sampai 5,94. Yang berart persepsi responden berada diposisi jawaban yang bergerak sari sangat tidak setuju sampai ke sangat setuju( 1 sampai 7) maka posisi jawaban berada bergesangat setuju karena sudah mendekati point 7 .

\section{Pengujian model dengan PLS}

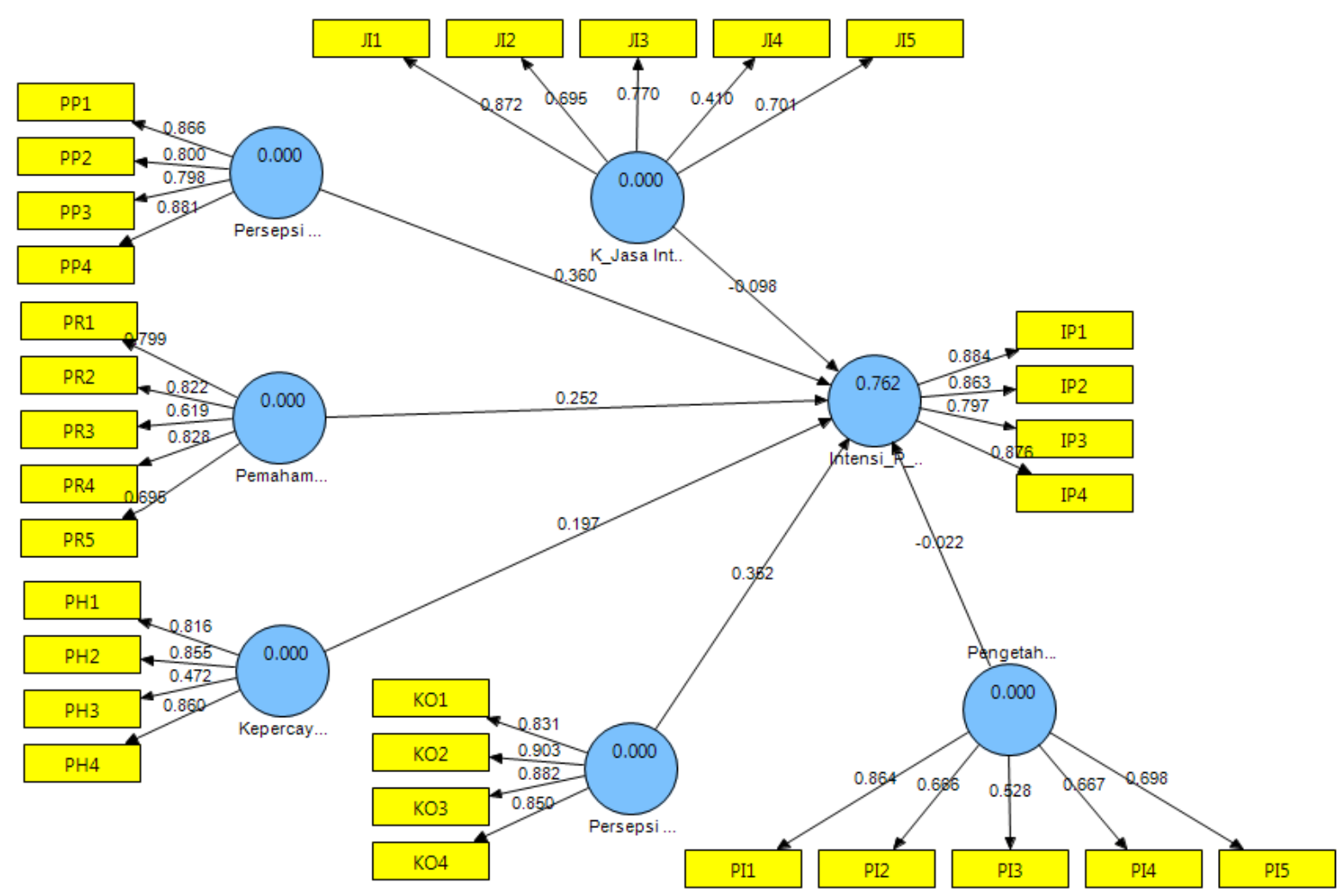

Gambar 2. Loading Factor 


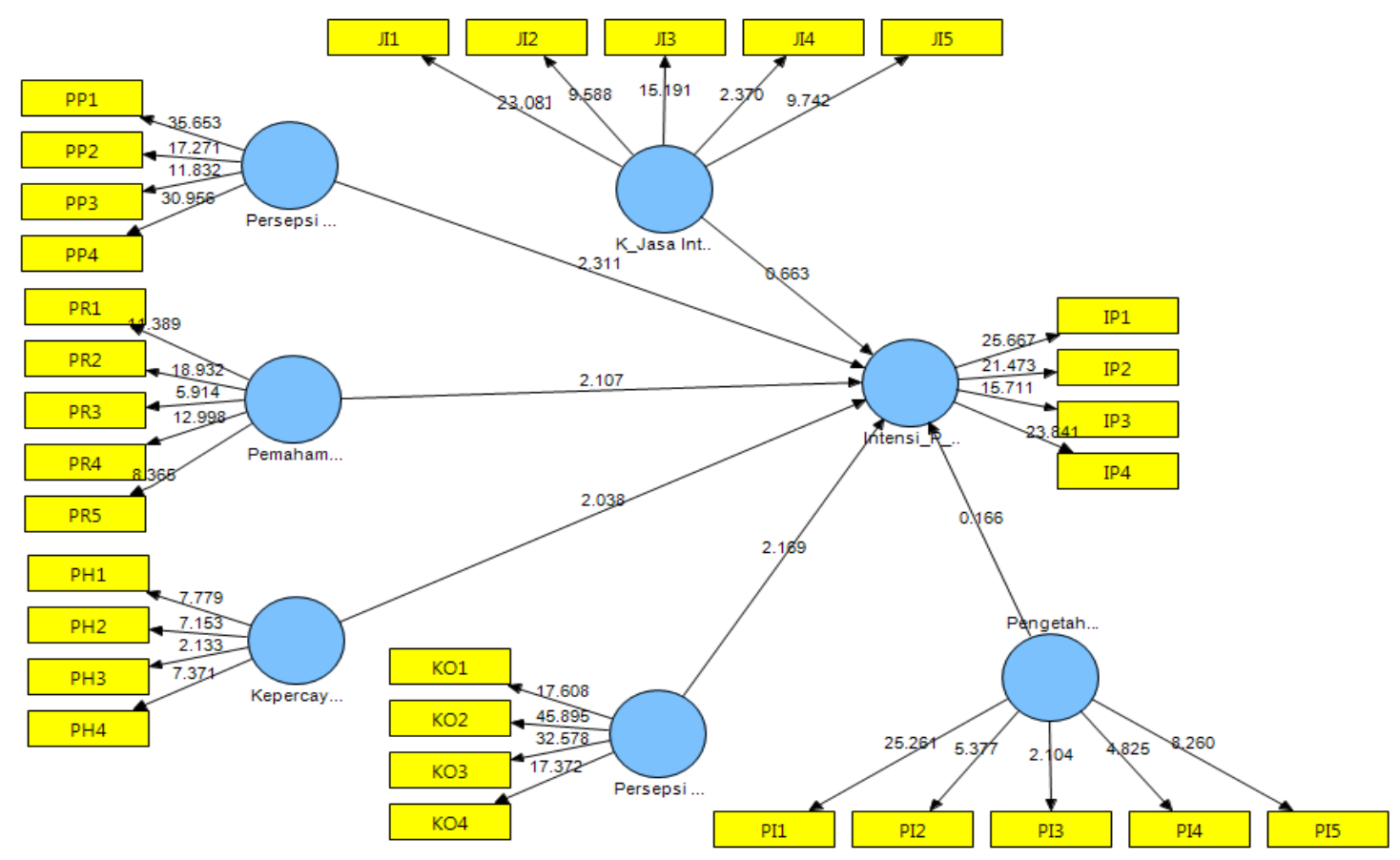

Gambar 3. Nilai t

\section{Uji validitas dan reliabilitas}

Berdasarkan hasil uji validitas, diketahui bahwa semua butir valid dan reliabel karena nilai loading factor $>0,05$ dan atau nilai t value $>1,96$ serta semua nilai reliabilitas $>0,6$.

\section{Ujihipotesis}

Gambar model $t$-values menampilkan diagram lintasan model lengkap dengan angka-angka yang menunjukkan nilai-t dari setiap angka hasil estimasi yang terkait.

Tabel 3. Hasil Analisis

\begin{tabular}{|c|c|}
\hline \hline & T Statistics (|O/STERR $)$ \\
\hline \hline Kualitas Jasa Internet -> Intensi_P_Konsumen & 0.663001 \\
\hline \hline Persepsi Penggunaan -> Intensi_P_Konsumen & 2.311026 \\
\hline \hline Pemahaman Risiko -> Intensi_P_Konsumen & 2.106656 \\
\hline \hline Persepsi Harga -> Intensi_P_Konsumen & 2.169022 \\
\hline \hline Kepercayaan Online -> Intensi_P_Konsumen & 2.038377 \\
\hline \hline Pengetahuan Internet -> Intensi_P_Konsumen & 0.165612 \\
\hline
\end{tabular}


Hasil analisis hipotesis 1 . diketahui bahwa nilai $\mathrm{t}=0.66$. Karena nilai $\mathrm{t}<1,96$ maka $_{0}$ diterima dan $\mathrm{H}_{1}$ ditolak, yang berarti kualitas jasa internet tidak berpengaruh signifikan terhadap intensi pembelian konsumen. Dengan demikian dapat diambil kesimpulan bahwa kualitas jasa internet tidak dapat digunakan untuk memprediksi intensi pembelian konsumen.

Hasil analisis hipotesis 2, diketahui bahwa nilai $\mathrm{t}=2.31$. Karena nilai $\mathrm{t}>1,96$ maka $\mathrm{H}_{0}$ ditolak dan $\mathrm{H}_{1}$ diterima, yang berarti persepsi penggunaan berpengaruh signifikan terhadap intensi pembelian konsumen. Dengan demikian dapat diambil kesimpulan bahwa persepsi penggunaan dapat digunakan untuk memprediksi intensi pembelian konsumen.

Hasil analisis hipotesis 3, diketahui bahwa nilai $\mathrm{t}=2.11$. Karena nilai $\mathrm{t}>1,96$ maka $\mathrm{H}_{0}$ ditolak dan $\mathrm{H}_{1}$ diterima, yang berarti pemahaman risiko berpengaruh signifikan terhadap intensi pembelian konsumen. Dengan demikian dapat diambil kesimpulan pemahaman risiko dapat digunakan untuk memprediksi intensi pembelian konsumen.

Hasil analisis analisis hipotesis 4 , diketahui bahwa nilai $\mathrm{t}=2.17$. Karena nilai $\mathrm{t}>1,96$ maka $\mathrm{H}_{0}$ ditolak dan $\mathrm{H}_{1}$ diterima, yang berarti persepsi harga berpengaruh signifikan terhadap intensi pembelian konsumen. Dengan demikian dapat diambil kesimpulan bahwa persepsi harga dapat digunakan untuk memprediksi intensi pembelian konsumen.

Hasil analisis hipotesis 5, diketahui bahwa nilai $\mathrm{t}=2.04$. Karena nilai $\mathrm{t}>1,96$ maka $\mathrm{H}_{0}$ ditolak dan $\mathrm{H}_{1}$ diterima, yang berarti kepercayaan online berpengaruh signifikan terhadap intensi pembelian konsumen. Dengan demikian dapat diambil kesimpulan bahwa kepercayaan online dapat digunakan untuk memprediksi intensi pembelian konsumen.

Hasil analisis hipotesis 6 , diketahui bahwa nilai $\mathrm{t}=0.17$. Karena nilai $\mathrm{t}<1,96$ maka $\mathrm{H}_{0}$ diterima dan $\mathrm{H}_{1}$ ditolak, yang berarti pengetahuan internet tidak berpengaruh signifikan terhadap intensi pembelian konsumen. Dengan demikian dapat diambil kesimpulan bahwa pengetahuan internet tidak dapat digunakan untuk memprediksi intensi pembelian konsumen.

\section{Pembahasan}

Beberapa peneliti menemukan bahwa keinginan konsumen untuk membeli secara online dipengaruhi oleh beberapa hal yaitu: kualitas jasa, persepsi penggunaan, pemahaman risiko, persepsi harga, pengetahuan internet, dan kepercayaan onlineNikhashemi, dkk. (2012). Sebelum menggunakan internet, konsumen harus terlebih dahulu memahami kegunaan internet. Internet dapat digunakan sebagai media komunikasi, penyedia informasi, transaksi online banking, dan belanja online.Selain itu penentuan harga di situs web dapat memberi dampak positif maupun negatif terhadap keputusan pembelian konsumen (Tzy-Wen Tang, et al., 2005). Untuk memahami risiko yang dapat terjadi jika melakukan pembelian secara online. Dalam konteks bisnis online, kepercayaan konsumen merujuk pada keyakinan dan ekspektasi mereka terhadap karakter penjual jasa online tersebut (Tzy-Wen Tang, et al., 2005).Kualitas jasa internet terdiri dari personalisasi, keamanan situs web, dan desain situs web. Kualitas jasa dapat ditentukan melalui perbedaan antara layanan yang diharapkan dengan layanan yang diterima atau dirasakan (Zeithaml, et al., 2002). Situs web yang dipilih konsumen adalah situs web yang berkualitas, maksudnya dapat memenuhi kebutuhan konsumen secara personal, dapat menjamin keamanan data konsumen, serta memiliki desain situs yang menarik. Faktor-faktor tersebut dapat menjadi hal utama yang dipikirkan oleh konsumen untuk menjadi faktor pendorong dalam mengkonsumsi sebuah jasa internet dan meningkatkan intensi pembelian. 
Sebelum menggunakan internet, konsumen harus terlebih dahulu memahami kegunaan internet. Internet dapat digunakan sebagai media komunikasi, penyedia informasi, transaksi online banking, dan belanja online. Jika konsumen ingin berbelanja tiket pesawat secara online, maka ia akan mencari informasi melalui internet tentang situs yang menyediakan jasa online ticketing. Kemudahan penggunaan situs web tersebut akan mempengaruhi intensi pembelian konsumen. Penentuan harga di situs web merupakan hal yang sensitif, kompleks, dan kritis. Hal tersebut dapat memberi dampak positif maupun negatif terhadap keputusan pembelian konsumen (TzyWen Tang, et al., 2005). Selain itu, konsumen juga harus memahami risiko yang dapat terjadi jika melakukan pembelian secara online. Risiko yang dapat terjadi seperti penipuan kartu kredit. Oleh karena itu, konsumen harus mempunyai pemahaman akan internet dan berbelanja di situs web yang terpercaya. Dalam konteks bisnis online, kepercayaan konsumen merujuk pada keyakinan dan ekspektasi mereka terhadap karakter penjual jasa online tersebut (Tzy-Wen Tang, et al., 2005).Kualitas jasa internet terdiri dari personalisasi, keamanan situs web, dan desain situs $w e b$. Kualitas jasa dapat ditentukan melalui perbedaan antara layanan yang diharapkan dengan layanan yang diterima atau dirasakan (Zeithaml, et al., 2002). Situs web yang dipilih konsumen adalah situs web yang berkualitas, maksudnya dapat memenuhi kebutuhan konsumen secara personal, dapat menjamin keamanan data konsumen, serta memiliki desain situs yang menarik. Faktor-faktor tersebut dapat menjadi hal utama yang dipikirkan oleh konsumen untuk menjadi faktor pendorong dalam mengkonsumsi sebuah jasa internet dan meningkatkan intensi pembelian.

Berdasarkan analisis yang dilakukan pada penelitian intensi pembelian konsumen tiket online menjukkan bahwa kualitas jasa internet tidak berpengaruh terhadap pembelian tiket online, hal ini tidak mendukung penelitian sebelumnya. Untuk persepsi pengguna, pemahaman risiko, persepsi harga, kepercayaan online, keempat variable ini menunjukkan hasil yang berpengaruh, artinya mendukung penelitian sebelumnya. Sedangkan pengetahuan internet tidak berpengaruh sehingga tidak mendukukung hasil penelitian sebelumnya. Perberdaannya ini dapat didasarkan atas beberapa hal, seperti perbedaan waktu pengumulan data, subyek berbeda dan ng sangat tersebar, teknik sampling yang digunakan. Selain itu intensi pembelian tiket sangat banyak faktor lainnya yang lebih menentukan dibandingkan kualias dan pengetahuan internet.

\section{KESIMPULAN DAN SARAN}

\section{Kesimpulan}

Beberapa kesimpulan penelitian adalah: 1). Kualitas jasa internet tidak berpengaruh signifikan terhadap intensi pembelian konsumen.2).Persepsi penggunaan berpengaruh signifikan terhadap intensi pembelian konsumen.3). Pemahaman risiko berpengaruh signifikan terhadap intensi pembelian konsumen.4).Persepsi harga kepada pelanggan berpengaruh terhadap intensi pembelian konsumen.5).Kepercayaan online berpengaruh terhadap intensi pembelian konsumen.6). Pengetahuan internet tidak berpengaruh terhadap intensi pembelian konsumen.

\section{Saran}

Perlu adanya perbaikan atas kualitas jasa tiket online dan pengetahuan internet terhadap tiket online, agar dapat menjadi dasar bagi intensi keputusan konsumen dalam melakukan pembelian. Selain itu untuk persepsi pengguna, pemahaman resiko, harga dan kepercayaan tiket secra online terus harus dapat ditingkatkan karena ke empat hal ini memberikan pengaruh pada intensi pembelian konsumen. 


\section{REFERENSI}

Aritonang, Lerbin R. (2007). Peramalan Bisnis. Ghalia, Jakarta

Ajzen, I. (2005). Attitudes, Personality, and Behaviour. $2^{\text {nd }}$ Edition. Milton-Keynes, Open University Press/ Mc Graw-Hill, England.

Barnes, S. J. dan Vidgen, R. (2006) "An Evaluation of Cyber-bookshops the WebQual Method".International Journal of Electronic Commerce. Vol. 6. hal. 11-30

Bart, Y., Shankar, V., Sultan, F. and Urban, G. (2005). "Are the drivers and role of online trust the same for all web sites and consumers A large-scale exploratory empirical study".Journal of Marketing, Vol. 69, pp. 133-52

Blackwell, Roger D., Miniard, Paul W., dan Engel, James F. (2006). Consumer Behaviour. $10^{\text {th }}$ Edition.Thomson, New York.

Cai dan Jun. (2003). "Internet Users' Perceptions of Online Service Quality: a Comparison of Online Buyers and Information Searchers". Managing Service Quality. Vol. 13. hal. 504519

Calin, G. (2003). 'Tailoring E-service Quality through CRM”. Managing service quality. Vol 13. hal. 520-531

Collier, J. E. dan Bienstock, C. C. (2006). "Managing Service Quality in E-retailing”. Journal of Service Research. Vol. 8(3). hal. 260-275

Dehbashi, Shima and Nasim Nahavandi. 2007. "Factors Affecting on Passengers Acceptance Towards Electronic Ticketing Provided By Airlines". Journal of Management Information Systems. Page 263-288: Tarbiat Modares University

Fassnacht M., Koese I. (2006), “Quality of Electronic Services,” Journal of Service Research, 9 (1), 19-37.

Gaertner, N., Smith, M. (2001)." E-Commerce in a web-based environment: auditingrelative advantages in The Australian Health Sector", Managerial Auditing Journal,16(6), 347-365.

Gefen, David (2002),"Customer Loyalty in E-Commerce,"Journal of the Association for Information Systems", Volume 3

Hair, Joseph F., et al. (1995). Multivariate Data Analysis. $4^{\text {th }}$ Edition. New Jersey: Prentice Hall

Kolsaker, A. \& Payne, C. (2002)."Engendering trust in e-commerce: a study of gender-based concerns", Marketing Intelligence \& Planning, Vol. 20, No.4.

Kuncoro, Mudrajad (2003), Metode Riset Untuk Bisnis dan Ekonomi. Penerbit Erlangga, Jakarta

Lichtenstein, D. R., Ridgway, N.M., andNetemeyer, R. G. 1993." Price Perception andConsumer Shopping Behaviour: A FieldStudy". Journal of Marketing.Vol. 30, No. 2,pp: 234-245.

Lin, H. H., \& Wang, Y .S. (2006). An examination of the determinants ofCustomerloyalty in mobile commerce contexts, Information \& Management, Vol. 43

McGee, M., Rich, A., and Dumas, J. (2004). Understanding the usability construct: Userperceived usability. In Proceedings of the Human Factors and Ergonomics Society 48th Annual Meeting (pp. 907-911). Santa Monica, CA: HFES

Naiyi, Y.E. (2004).Dimensions of consumer perceived risk in online shopping. Journal of Electronic Science and Technology of China.2(3),177-182

Nikhashemi, Haque, Yamin dan Khatibi, 2012, Service Quality and Consumer Purchasing Intention Towaard Online Ticketing: An Empirical Study in Iran. Iran Journal of Management 1(1): 1-13 
Pavlou, P.A. \&Fygenson, M. (2006). Understanding and predicting electronic commerce adoption: an extension of the theory of planned behavior, MISQuarterly, Vol. 30 No. 1.

Peter, J. Paul dan Jerry C Olson. (2000). Consumer behavior: Perilaku Konsumen dan Strategi Pemasaran Jilid 1. Edisi Keempat. Jakarta: Erlangga.

Potosky, Denise.,(2002)A field study f computer beliefs as an computer knowledge and ferformance during training".Computers Human in behavior 18, 241-255

Rossiter, John R, Larry Percy. (1998). Advertising Communication and Promotion Management, Edisi Kedua, McGraw-Hill.Singapura .

Stone, RN. and K. Gronhaug. 1993. "PerceivedRisk: Further Considerations for theMarketing Discipline". European Journalof Marketing. 27 (3). 39-50.

Tan, S. J. (1999).” Strategies for Reducing consumer's risk aversion in Internet Shopping. Journal of Consumer Marketing”, 163-178.

Tzy-Wen Tang and Wen- Hai Chi. (2005) "The role of trust in customer online shopping behavior: Perspectiveof technology Acceptance model" Available at http://www.casos.cs.cmu.edu/events/

VanderHeijden, H., Verhagen, T., \&Creemers, M. (2003).Understandingonline purchase intentions: contributions from technology and trust perspectives. European Journal of Information Systems, 12(1), 41-48. doi:10.1057/palgrave.ejis.3000445

Yang, Z. (2001), "Customer Perceptions of Service Quality in Internet-based Electronic Commerce".Proceedings of the $30^{\text {th }}$ EMAC Conferencein Bergen. Pp. 37-44

Zeithaml, V. A., Parasuraman, A., dan Malhotra, A. (2002). "E-service Quality: Definitions, Dimensions, and Conceptual Model". Working Paper. Cambridge, MA: Marketing Science Institut

Zhang, L., Tan, W., Xu, Y., \& Tan, G. (2012). Dimensions of online privacy concern and its influence on privacy protection behaviors among young adolescents. Journal of Consumer Affairs, 8-14. 